\title{
Immunological Features of Measles in Children
}

\author{
Svetlana Chechetova', Rahat Kadyrova', Zuura Dzholbunova', Elmira Mainazarova', \\ Elena Khalupko', Yethindra Vityala ${ }^{3}$, Tugolbai Tagaev ${ }^{4}$ \\ ${ }^{1}$ Department of Children's Infectious Diseases, I.K. Akhunbaev Kyrgyz State Medical Academy, Bishkek, Kyrgyzstan. \\ ${ }^{2}$ Department of Epidemiology and Immunology, Kyrgyz-Russian Slavic University, Bishkek, Kyrgyzstan. \\ ${ }^{3}$ Department of Pathology, International Higher School of Medicine, International University of Kyrgyzstan, Bishkek, Kyrgyzstan. \\ ${ }^{4}$ Department of Public Health and Healthcare, I.K. Akhunbaev Kyrgyz State Medical Academy, Bishkek, Kyrgyzstan. \\ DOI: https://doi.org/10.24321/0019.5138.202134
}

\section{I $\mathbf{N} \quad \mathbf{F} \mathbf{O}$}

\section{Corresponding Author:}

Yethindra Vityala, Department of Pathology, International Higher School of Medicine, International University of Kyrgyzstan, Bishkek, Kyrgyzstan.

E-mail Id:

yethindravityala10@gmail.com

Orcid Id:

https://orcid.org/0000-0003-1007-2422

How to cite this article:

Chechetova S, Kadyrova R, Dzholbunova Z, Mainazarova E, Khalupko E, Vityala Y, Tagaev T. Immunological Features of Measles in Children. J Commun Dis. 2021;53(3):11-15.

Date of Submission: 2021-06-03

Date of Acceptance: 2021-09-27

\section{$\begin{array}{llllllll}\mathbf{A} & \mathbf{B} & \mathbf{S} & \mathbf{T} & \mathbf{R} & \mathbf{A} & \mathbf{C} & \mathbf{T}\end{array}$}

Background: Despite the availability of a safe and effective vaccine, measles remains endemic in many countries and is the main cause of morbidity and mortality among young children. Therefore, the main objective of the study was to investigate the immunological features of measles in children.

Materials and Methods: The immune status of children $(n=72)$ who were diagnosed with measles, was analysed. Various lymphocyte proportions were determined using monoclonal antibodies and immunofluorescence microscopy. The immunoregulatory index was calculated.

Results: The relative content of $\mathrm{CD} 4^{+}$and $\mathrm{CD} 8^{+} \mathrm{T}$ cells in the experimental group comprising of moderately and severely ill patients was significantly lower. The immunoregulatory index was reduced, and there was a positive correlation ( 0.3 ) between the indices during admission (2.0469 $\pm 0.04830)$ and during the entire hospital stay $(1.9258 \pm 0.09099)$ in moderately ill patients, respectively. The proportion of $\mathrm{CD} 16^{+} \mathrm{T}$ cells was higher at admission and the rate of the increase in $\mathrm{CD} 16^{+} \mathrm{T}$ cell proportion was significantly higher $(P<0.05)$. $C D 16^{+}$counts were higher in moderate to severe cases. Thus, moderately and severely ill children with measles exhibited T-cell immune deficiency.

Conclusion: The severity of measles directly correlated with the patient age, with the disease progressing to the severe status in younger children $(r=-0.3)$.

Keywords: Measles, Children, Clinical Course, Anergy, Lymphocytes, Immune Memory, Immunosuppression

\section{Introduction}

Despite the availability of a safe and effective vaccine against measles, the disease remains endemic in many countries and is the main cause of morbidity and mortality among young children. ${ }^{1,2}$ The measles vaccine promotes formation of high-affinity $\mathrm{CD}^{+}$and $\mathrm{CD} 8^{+} \mathrm{T}$ cells and generates measles- specific memory $\mathrm{T}$ cells by inducing a long-lived T-cell memory response in subjects. ${ }^{3}$

In Kyrgyzstan, the number of patients with measles has been on a rise since 2018. According to the Republican Center for Immuno-prophylaxis, the Ministry of Health, Kyrgyzstan, 2,345 cases of measles were reported in 2019. 
Among them, $45.6 \%$ included children under the age of 1 year, who did not receive vaccination due to their age. Analysis of the vaccination status revealed that 2,114 patients (children and adults) were unvaccinated, while only 231 (9.9\%) patients were vaccinated against measles. ${ }^{4}$

The measles virus (MV) infects and functionally damages immune cells, resulting in the development of secondary bacterial and viral infections. ${ }^{5} \mathrm{~T}$ follicular helper $\left(\mathrm{T}_{\mathrm{FH}}\right)$ cells, a subpopulation of $\mathrm{CD}^{+} \mathrm{T}$ cells, play an important role in the development of antigen-specific B-cell immunity that leads to a long-term serological memory. ${ }^{6,7} \mathrm{~T}_{\mathrm{H}} 1 \mathrm{CD}^{+}$ lymphocytes activate macrophages ${ }^{8}$ that phagocytose cells infected with MV and eliminate them. In addition, specific $\mathrm{CD}^{+} \mathrm{T}$ cells control the replication and elimination of $\mathrm{MV}^{9}$ by detecting viral antigens on the surface of infected cells and neutralising them.

The MV can erase immune memory in infected individuals, impairing the body's ability to fight other diseases that the body is already immune to. ${ }^{10,11}$ Since MV affects both adaptive immunity (content and functional activity of $T$ and $B$ lymphocytes) and innate immunity (phagocytic cells and natural killer (NK) cells) ${ }^{12}$, we aimed to investigate the immunological features of measles in children.

\section{Materials and Methods}

\section{Patients and Ethical Approval}

Seventy-two children and adolescents, who were diagnosed with measles and hospitalised at the Republican Clinical Infectious Diseases Hospital between May 2018 and December 2019, were investigated for this study. Inclusion criteria for patients will be as follows: (i) children from 1 month to 14 years old with a diagnosis of measles, (ii) and children with moderate to severe measles. Exclusion criteria for patients will be as follows: (i) adults diagnosed with measles, (ii) children and adults with other infectious diseases, and (iii) children with mild measles. The diagnosis of measles was made primarily on the basis of typical, pathogenic symptoms of the disease, as well as laboratory research data (PCR, ELISA diagnostics). Confidentiality of the patient data was maintained, and the parents or legal guardians provided informed consent for this study, which was approved by the I. K. Akhunbaev Kyrgyz State Medical Academy Bioethics Committee (Protocol No. 2 dated April 19, 2017).

\section{The Criteria for the Severity}

The criteria for categorising the patients as "severe" were: the severity of symptoms of intoxication, the duration of fever, the development of complications such as pneumonia, the presence of respiratory failure, the duration of the disease, as well as the premorbid background of the child.

\section{Evaluation of Lymphocytes}

The study determined the proportions of the following types of lymphocytes using their respective monoclonal antibodies and immunofluorescence microscopy (AxioSkop 40, Zeiss, Marlly-le-Roi, France): $\mathrm{CD}^{+}$(T lymphocytes), $\mathrm{CD}^{+}$(helper T cells), CD8 ${ }^{+}$(cytotoxic T lymphocytes), $\mathrm{CD}_{19}{ }^{+}$(B lymphocytes), and $\mathrm{CD} 16^{+}$(NK cells). The $\mathrm{CD}^{+} /$ $\mathrm{CD}^{+}$ratio, also termed the immunoregulatory index (IRI), was calculated. Circulating immune complexes (CIC) were evaluated by precipitation with $3.5 \%$ polyethylene glycol 6000 (Sigma-Aldrich, St. Louis, MO, USA) and measuring the optical density using a spectrophotometer.

\section{Statistical Analyses}

Sample correlation coefficient ( $r$ ) was used for correlation analysis. The data are presented as the mean \pm standard deviation and $n(\%)$. The Mann-Whitney test was used to assess the significance of differences between the groups. A two-sided $\mathrm{P}<0.05$ was considered statistically significant. All statistical analyses were performed using the Statistical Package for Social Sciences (SPSS) software version 15 for Windows.

\section{Results}

Patient data revealed that the majority $(68.0 \%)$ of patients were younger than 3 years of age. More than $18.1 \%$ of patients were aged between 3 and 6 years, who were unvaccinated for various reasons. Based on these data, we concluded that the majority of children (86.1\%) were not vaccinated against MV.

Analysis of disease severity in the afflicted children indicated that $43.1 \%(n=31)$ of the patients had severe disease, while $56.9 \%$ of the patients $(n=41)$ had moderate disease. Patients became severely ill, because of the development of acute syndromes, such as respiratory failure due to severe croup development (31.9\%) and lower respiratory obstruction (8.3\%), which arose due to acute respiratory viral co-infection and bacterial pneumonia (40.0\%). Only $4.6 \%$ of children with measles were in the intensive care unit; the severity of the condition was attributed to the decreased immunity caused by the acute anergy associated with measles.

A negative correlation ( $r=-0.3$ ) was found between the age and severity of the disease in children of different age groups, i.e., younger the patient, higher was the rate of progression to the severe status. This can be attributed to inadequate or lack of immune responses in young children, especially in those who were not vaccinated. A positive correlation was observed between the severity of a patient condition and the following parameters: duration of hospital stay $(r=0.5)$, maximum body temperature $(r=0.38)$, and duration of medication $(r=0.37)$.

Analysis of the immunological data revealed a shift in the lymphocyte composition and humoral responses observed at the time of admission and during hospital stay 
(Table 1). The proportion of $\mathrm{CD}^{+}$lymphocytes tended to increase (33.347 $\pm 0.9656 ; 34.258 \pm 1.2269)$, and a positive correlation was observed $(0.8 ; 0.7)$. This was primarily attributed to the expansion of peripheral $\mathrm{CD}^{+}$cells, and the $\mathrm{CD}^{+}$and $\mathrm{CD} 16^{+}$cells, which are the main contributors to antiviral defence. Patients in both groups exhibited a significant deficit $(P<0.05)$ in the relative content of total $\mathrm{CD}^{+} \mathrm{T}$ cells, when compared to that in healthy children ( $n=25)$ (Table 2).

The relative content of $\mathrm{CD}^{+} \mathrm{T}$ cells in moderately and severely ill patients was significantly lower compared to that in the control group $(P<0.05)$. There was a tendency for an increase in the number of $\mathrm{CD}^{+} \mathrm{T}$ cells $(22.583 \pm 0.6475$; $23.581 \pm 0.8735)$ in moderately and severely ill patients and a positive correlation was observed $(0.8 ; 0.6)$ between the number of $\mathrm{CD}^{+} \mathrm{T}$ cells on admission and that during the hospital stay. The proportion of $\mathrm{CD}^{+} \mathrm{T}$ cells at admission and at discharge was higher, but not statistically significant in moderately ill patients than in severely ill patients $(P>$ $0.05)$. This could possibly be attributed to the early blood sampling (2-4 days after the first collection), as the average hospital stay was $6.6 \pm 2.7$ days in moderately ill patients.

The dynamics of the immunological parameters in relation to the number of $\mathrm{CD}^{+} \mathrm{T}$ cells were less pronounced; however, there was a statistically significant $(P<0.05)$ increase in their number $(11.542 \pm 0.4015 ; 12.452 \pm 0.7076)$. As in moderate and severe measles, a positive correlation was observed $(0.8 ; 0.3)$ between the number of $\mathrm{CD}^{+} \mathrm{T}$ cells at admission and during the hospital stay. There was a significant decrease $(P<0.05)$ in the relative content of $\mathrm{CD}^{+} \mathrm{T}$ cells in the patient group compared to that in the control group.

$\mathrm{CD}^{+}$and $\mathrm{CD}^{+} \mathrm{T}$ cells play an important role in regulating the body's immune response. The IRI values of moderately and severely ill patients differed significantly from that of the control. Eventually, IRI decreased (2.0469 \pm 0.04830 ; $1.9258 \pm 0.09099$ ) in moderately ill patients, and a positive correlation was observed ( 0.3 ) between the IRI at admission and during the hospital stay. We observed that higher the IRI at admission, more pronounced was the increase in the IRI during the hospital stay. The decrease in the IRI was higher in moderately ill patients; however, there were no significant differences $(P>0.05)$.

During both the admission (acute phase) and the hospital stay, children with measles exhibited a significant decrease in the number of $\mathrm{CD} 16^{+}$cells (NK cells) compared with the control group $(P<0.05)$. During the hospital stay, the number of NK cells increased significantly $(9.903 \pm 0.3922$; $11.194 \pm 0.5818 ; P<0.05)$, and a positive correlation was observed ( 0.7 ) between the number of NK cells at admission and during the hospital stay, in both moderately and severely ill patients. The higher the number of $\mathrm{CD} 16^{+}$cells upon admission, the more pronounced was the increase in the number of NK cells during the hospital stay. The number of $\mathrm{CD}_{16} 6^{+}$cells was higher in moderately ill patients during admission; however, the rate of increase in $\mathrm{CD}^{+} 6^{+}$ cell number was statistically significant only in severely ill patients $(P<0.05)$.

Table I.Comparative Analysis of the Immunological Parameters in Children with Measles

\begin{tabular}{|c|c|c|c|}
\hline Immunological Parameters & Upon Admission (1) $\mathbf{n}=\mathbf{7 2}$ & Mid-stay in Hospital (2) $\mathbf{n}=\mathbf{3 1}$ & P-value \\
\hline T-lymphocytes (CD3+) & $33.347 \pm 0.9656$ & $34.258 \pm 1.2269$ & $\mathrm{P}>0.05$ \\
\hline T-helpers (CD4+) & $22.583 \pm 0.6475$ & $23.581 \pm 0.8735$ & $\mathrm{P}>0.05$ \\
\hline B-lymphocyte (CD19+) & $21.764 \pm 0.5959$ & $20.452 \pm 0.7604$ & $\mathrm{P}>0.05$ \\
\hline Cytotoxic T lymphocytes (CD8+) & $11.542 \pm 0.4015$ & $12.452 \pm 0.7076$ & $\mathrm{P}<0.05$ \\
\hline Natural killer cells (CD16+) & $9.903 \pm 0.3922$ & $11.194 \pm 0.5818$ & $\mathrm{P}<0.05$ \\
\hline Immunoregulatory index & $2.0469 \pm 0.04830$ & $1.9258 \pm 0.09099$ & $\mathrm{P}>0.05$ \\
\hline Circulating immune complexes & $130.823 \pm 3.4260$ & $123.210 \pm 4.8333$ & $\mathrm{P}>0.05$ \\
\hline
\end{tabular}

Table 2.Comparative Analysis of the Immunological Parameters in Children with Measles and Healthy Children

\begin{tabular}{|c|c|c|c|c|}
\hline $\begin{array}{c}\text { Immunological } \\
\text { Parameters }\end{array}$ & $\begin{array}{c}\text { Moderately III Patients } \\
\text { (Upon Admission) } \mathbf{n = 4 1}\end{array}$ & $\begin{array}{c}\text { Severely III Patients } \\
\text { (Upon Admission) } \mathbf{n = 3 1}\end{array}$ & $\begin{array}{c}\text { Healthy Children } \\
\mathbf{n}=\mathbf{2 5}\end{array}$ & P-value \\
\hline $\begin{array}{c}\text { Cytotoxic T } \\
\text { lymphocytes (CD8+) }\end{array}$ & $11.854 \pm 3.5746$ & $11.129 \pm 3.1806$ & $16.2 \pm 3.45$ & $\mathrm{P}<0.05$ \\
\hline $\begin{array}{c}\text { Natural killer cells } \\
\text { (CD16+) }\end{array}$ & $10.244 \pm 3.8521$ & $9.452 \pm 2.4609$ & $16.5 \pm 2.0$ & $\mathrm{P}<0.05$ \\
\hline $\begin{array}{c}\text { Immunoregulatory } \\
\text { index }\end{array}$ & $2.0173 \pm 0.35867$ & $2.0861 \pm 0.47249$ & $1.9 \pm 0.1$ & $\mathrm{P}>0.05$ \\
\hline
\end{tabular}


During the hospital stay, the number of $\mathrm{CD} 19^{+}$cells tended to decrease ( $21.764 \pm 0.5959 ; 20.452 \pm 0.7604)$. A positive correlation was observed $(0.9 ; 0.7)$ between the number of $\mathrm{CD} 19^{+}$cells at admission and during the hospital stay, in both moderately and severely ill patients.

In our study, the $\mathrm{CIC}$ at admission was higher in moderately ill patients than in severely ill patients. The CIC decreased significantly $(P<0.05)$ in moderately ill patients, while it increased in severely ill patients, during the hospital stay.

\section{Discussion}

More than $50 \%$ of the patients in this study were children under 1 year of age and they were not vaccinated as they were below the recommended age for vaccination. ${ }^{13}$ According to the National Calendar plan in Kyrgyzstan, the first vaccination is carried out at the age of 1 year and re-vaccination at 6 years.

In measles patients, persisting infected cells may be responsible for the continued activation of CD4+ T cells, and as a result, the number of activated CD4+ T cells in circulation decreases much more slowly. ${ }^{14}$ Depletion of $\mathrm{CD} 8^{+}$ T cells leads to higher and prolonged viremia, ${ }^{9}$ indicating the importance of $\mathrm{CD}^{+} \mathrm{T}$ cells in viral control.

A decrease in the number of NK cells in measles is a pathognomonic sign of effector cell immunodeficiency caused due to disease severity. NK cells are an essential component of antiviral immunity ${ }^{15}$ and they contribute to immune defence by regulating adaptive immunity. ${ }^{16}$ NK cells suppress $C D 4^{+} T_{F H}$ cells during the early phase of infection and inhibit the induction of humoral immunity and memory T cells in the subsequent acute infections. ${ }^{17}$

In the experimental group, the parameters of humoral immunity remained the same during admission and hospital stay. No significant change was observed in the number of $\mathrm{CD} 19^{+}$lymphocytes among patients with measles of varying severity compared with that in healthy controls. $A$ decrease in the relative content of B-lymphocytes in severely ill patients could be a compensatory-redistributive process or a consequence of active elimination of MV by the components of antiviral immunity ( $C D 8^{+} \mathrm{T}$ cells). A study on 77 unvaccinated children showed that $11-73 \%$ of the measured antibodies, specific to different pathogens, were lost following an MV infection, which in turn, influenced humoral immunity in these children. ${ }^{10}$

Higher the number of $\mathrm{CD} 19^{+}$cells at admission, more pronounced was the increase in number of CD19+ cells during the hospital stay. B-lymphocyte counts were also higher in patients with moderate-to-severe disease. The tendency towards the normalization of B cell numbers may be associated with the preservation of humoral immunity. Sequencing of B cells harvested from patients pre- and post-MV infection indicated incomplete restoration of the naive $B$ cell pool and a depletion in the B memory cells. ${ }^{11}$

During humoral immune response in measles patients, there is an increase in the $\mathrm{CIC}$ during the initial phase of the disease, which tends to normalize over time. The increase in the number of $\mathrm{CIC}$ in severely ill patients combined with the anergy and the presence of excess antigens, such as bacteria and viruses, leads to secondary bacterial and viral infections. ${ }^{5} \mathrm{~A}$ decrease in the number of $\mathrm{CIC}$ in moderately ill patients is of diagnostic value, as it indicates a positive response to therapy.

When assessing the clinical and immunological parameters in children with measles, it is important to consider the physiological characteristics of the immune system, such as incomplete phagocytic ability of cells, immature NK cells, decreased interferon synthesis, increased lysozyme synthesis, and high activity of the thymus.

\section{Conclusion}

In our study, the severity of measles directly correlated with the patient age, showing that the disease progressed to a more severe status $(r=-0.3)$ in younger children. We found a correlation between the severity of disease and the development of immune responses in children with measles. In moderately and severely ill children, T-cell immune deficiency was observed because of a significant reduction in the relative number of $\mathrm{CD}^{+}, \mathrm{CD}^{+}, \mathrm{CD}^{+}$, and CD16 ${ }^{+} \mathrm{T}$ cells.

\section{Author Contributions}

Conception, design of the work, manuscript preparation, and data acquisition: Svetlana Chechetova, Rahat Kadyrova, Zuura Dzholbunova, Elmira Mainazarova, Elena Khalupko, Yethindra Vityala, and Tugolbai Tagaev. Clinical management: Svetlana Chechetova, Rahat Kadyrova, Zuura Dzholbunova, Elmira Mainazarova, and Yethindra Vityala. Manuscript preparation and data acquisition: Yethindra Vityala, Svetlana Chechetova, and Rahat Kadyrova.

\section{Availability of Data and Material}

Data are available from the corresponding author upon reasonable request.

\section{Acknowledgements: None}

\section{Funding: None}

\section{Conflict of Interest: None}

\section{References}

1. Mclntosh N, Helms P, Smyth R, Logan S. Forfar and Arneil's Textbook of Pediatrics. 7th ed. Edinburgh: Churchill Livingstone; 2008.

2. World Health Organization [Internet]. Causes of child mortality; [2020 Sep 8]. Available from: http://www. who.int/gho/child_health/mortality/causes/en/ 
3. Ovsyannikova IG, Dhiman N, Jacobson RM, Vierkant RA, Poland GA. Frequency of measles virus-specific CD4+ and CD8+ $T$ cells in subjects seronegative or highly seropositive for measles vaccine. Clin Diagn Lab Immunol. 2003 May;10(3):411-6. [PubMed] [Google Scholar]

4. Ministry of Health of the Kyrgyz Republic [Internet]. Measles has not been reported in Kyrgyzstan since June of this year, 2019; [cited 2020 Sep 8]. Available from: http://med.kg/en/news/221-measles-has-not-beenreported-in-kyrgyzstan-since-june-of-this-year.html

5. Griffin DE. Measles virus-induced suppression of immune responses. Immunol Rev. 2010 Jul;236:17689. [PubMed] [Google Scholar]

6. Crotty S. Follicular helper CD4 T cells (TFH). Annu Rev Immunol. 2011;29:621-63. [PubMed] [Google Scholar]

7. Qin L, Waseem TC, Sahoo A, Bieerkehazhi S, Zhou $\mathrm{H}$, Galkina EV, Nurieva R. Insights into the molecular mechanisms of $\mathrm{T}$ follicular helper-mediated immunity and pathology. Front Immunol. 2018 Aug;9:1884. [PubMed] [Google Scholar]

8. Janeway CA Jr, Travers P, Walport M, Shlomchik M. Immunobiology: The immune system in health and disease. 5th ed. Taylor \& Francis, Inc; 2001.

9. Permar SR, Klumpp SA, Mansfield KG, Kim WK, Gorgone DA, Lifton MA, Williams KC, Schmitz JE, Reimann KA, Axthelm MK, Polack FP, Griffin DE, Letvin NL. Role of $\mathrm{CD} 8(+)$ lymphocytes in control and clearance of measles virus infection of rhesus monkeys. J Virol. 2003;77(7):4396-400. [PubMed] [Google Scholar]

10. Mina MJ, Kula T, Leng $Y$, Li M, de Vries RD, Knip $M$, Siljander H, Rewers M, Choy DF, Wilson MS, Larman HB, Nelson AN, Griffin DE, de Swart RL, Elledge SJ. Measles virus infection diminishes preexisting antibodies that offer protection from other pathogens. Science. 2019 Nov;366(6465):599-606. [PubMed] [Google Scholar]

11. Petrova VN, Sawatsky B, Han AX, Laksono BM, Walz L, Parker E, Pieper K, Anderson CA, de Vries RD, Lanzavecchia A, Kellam P, von Messling V, de Swart $\mathrm{RL}$, Russell CA. Incomplete genetic reconstitution of $B$ cell pools contributes to prolonged immunosuppression after measles. Sci Immunol. 2019 Nov;4(41):eaay6125. [PubMed] [Google Scholar]

12. Flint PW, Haughey BH, Lund VJ, Niparko JK, Robbins KT, Thomas JR, Lesparence MM. Cummings Otolaryngology: Head and Neck Surgery. 5th ed. Mosby Elsevier. 2010;597-8.

13. Ma C, Gregory CJ, Hao L, Wannemuehler KA, Su Q, An Z, Quick L, Rodewald L, Ma F, Yan R, Song L, Zhang Y, Kong $Y$, Zhang $X$, Wang $H$, Li L, Cairns L, Wang N, Luo $H$. Risk factors for measles infection in 0-7 month old children in China after the 2010 nationwide measles campaign: A multi-site case-control study, 2012-2013.
Vaccine. 2016 Dec;34(51):6553-60. [PubMed] [Google Scholar]

14. Ryon JJ, Moss WJ, Monze M, Griffin DE. Functional and phenotypic changes in circulating lymphocytes from hospitalized Zambian children with measles. Clin Diagn Lab Immunol. 2002 Sep;9(5):994-1003. [PubMed] [Google Scholar]

15. Lanier LL. Evolutionary struggles between NK cells and viruses. Nat Rev Immunol. 2008 Apr;8(4):259-68. [PubMed] [Google Scholar]

16. Welsh RM, Waggoner SN. NK cells controlling virusspecific T cells: Rheostats for acute vs. persistent infections. Virology. 2013 Jan;435(1):37-45. [PubMed] [Google Scholar]

17. Rydyznski C, Daniels KA, Karmele EP, Brooks TR, Mahl SE, Moran MT, Li C, Sutiwisesak R, Welsh RM, Waggoner $\mathrm{SN}$. Generation of cellular immune memory and B-cell immunity is impaired by natural killer cells. Nat Commun. 2015 Feb;6:6375. [PubMed] [Google Scholar] 